\title{
Oedema, infiltration and drainage of connective tissue in rheumatoid arthritis - a preliminary report
}

\author{
Obrzęk, nacieki i drenaż tkanki łącznej w reumatoidalnym \\ zapaleniu stawów - doniesienie wstępne
}

\author{
Emília Rovenská, Jozef Rovenský \\ National Institute of Rheumatic Diseases, Piešt’any, Slovakia \\ National Institute of Rheumatic Diseases, Pieszczany, Słowacja
}

Key words: synovial membrane, lymphatic capillaries, specialized inter-endothelial junctions, immune cell trafficking.

Słowa kluczowe: błona maziowa, włosowate naczynia limfatyczne, wyspecjalizowane połączenia między komórkami śródbłonka, migracja komórek układu odpornościowego.

\section{Summary}

Objective: The aim of the study was to visualize lymphatic capillaries (LC) in synovial membrane obtained during synovectomy from patients with rheumatoid arthritis (RA) and juvenile idiopathic arthritis (IIA)

Material and methods: Specialized inter-endothelial junctions (e.g. endothelial microvalves) were visualized under both a transmission electron microscope (Figs. 1a, b) and light microscope (Figs. 1c, d). These openable junctions enable trafficking of immune cells and drainage of surplus tissue fluid from the interstitium of connective tissue in synovial membrane into prenodal lymph and play a substantial role in the drainage function of $L C$ in synovial joints.

Results: Lymphocytes, macrophages and some debris were found in lumens of LC under the light microscope (Fig. 2). Numerous infiltrates of immune cells in the interstitium of synovial membrane located predominantly around postcapillary venules and in the vicinity of LC (Fig. 3) were observed.

Conclusion: The role of endothelial microvalves in drainage of inflammatory infiltrates into lymphatic capillaries deserves further investigation.

\section{Streszczenie}

Cel pracy: Zobrazowanie włosowatych naczyń limfatycznych w błonie maziowej pobranej podczas synowektomii u pacjentów z reumatoidalnym zapaleniem stawów (RZS) oraz młodzieńczym idiopatycznym zapaleniem stawów (MIZS).

Materiał i metody: Do zdjęć obrazujących wyspecjalizowane połączenia między komórkami śródbłonka (np. mikrozastawki śródbłonka) wykorzystano zarówno transmisyjny mikroskop elektronowy (ryc. 1 a, b), jak i podmikroskop świetlny (ryc. 1 c, d). Omawiane połączenia, otwierając się, umożliwiają przemieszczanie się komórek odpornościowych i drenaż nadmiaru płynu tkankowego z przestrzeni śródmiąższowej tkanki łącznej błony maziowej do chłonki przedwęzłowej i mają istotne znaczenie dla funkcji drenującej kapilar limfatycznych w stawach maziówkowych.

Wyniki: W świetle włosowatych naczyń limfatycznych badanych pod mikroskopem świetlnym stwierdzono obecność limfocytów, makrofagów oraz pewną ilość resztek komórkowych (ryc. 2). Zaobserwowano liczne nacieczenia komórkami układu odpornościowego w przestrzeni śródmiąższowej błony maziowej, przeważnie umiejscowione wokót żylnych naczynek pozawłosowatych oraz w pobliżu kapilar limfatycznych (ryc. 3).

Wniosek: Określenie roli mikrozastawek śródbłonka w drenażu nacieków zapalnych do włosowatych naczyń limfatycznych wymaga dalszych badań.

Address for correspondence:

Prof. Jozef Rovenský, MD, DSc, FRCP, National Institute of Rheumatic Diseases, Nábrežie I. Krasku 4, 92112 Piešt’any, Slovak Republic, e-mail: jozef.rovensky@nurch.sk

Submitted: 31.05 .2012 


\section{Introduction}

Rheumatoid arthritis (RA) is often associated with oedema of synovial joints. In some patients, recurrent bilateral oedemas of lower limbs were described with no cardiac, renal or other identifiable cause. Sometimes they developed around the joint due to acute inflammation (e.g. around the ankle), but often their origin could not be precisely determined. Therefore, several rheumatologists have investigated the aetiology of oedema in RA [1-3].

Therapies that maintain or restore lymphatic function may represent important strategies for limiting inflammation [4]. It was revealed that TNF (tumor necrosis factor) blockade promotes proliferation of lymphatic vessels in the inflamed synovium of RA patients. The authors assumed that promotion of lymphangiogenesis may play an important part in efflux of cells and fluid out of the inflamed tissue [5].

In our work we visualized lymphatic capillaries (LC) which have an important function in drainage of connective tissue - a structural component of many organs in the human body, including synovial joints.

In the human synovial joint LC were studied by histochemical methods [5-7] and by the method of transmission electron microscopy $[8,9]$.

In this work we report some morphological findings on synovial LC and clear differentiation of their structure from blood capillaries and venules.

\section{Material and methods}

Synovial tissue was obtained during synovectomy of knee joints from RA and IIA patients. All patients, four women and one man, gave written informed consent. An overview of patients is presented in Table I. Tissue samples were fixed for $4 \mathrm{~h}$ in $3 \%$ glutaraldehyde, postfixed in $\mathrm{OsO}_{4}$, dehydrated in ethanol, passed through propylene oxide and embedded in Durcupan ACM (Fluka, Buchs, Switzerland). Semithin $(0.5 \mu \mathrm{m})$ sections were cut on LKB-Huxley (Bromma, Sweden) or Leica ULTRACUT R (Wien, Austria) ultramicrotomes and stained with toluidine blue.

\section{Wstęp}

Reumatoidalnemu zapaleniu stawów (RZS) często towarzyszy obrzęk stawów maziówkowych. U niektórych pacjentów opisywano nawracające obustronne obrzęki kończyn dolnych bez uchwytnych przyczyn kardiologicznych, nefrologicznych czy też innych możliwych do zidentyfikowania powodów. Niekiedy obrzęki rozwijaty się w okolicy stawów w wyniku ostrego procesu zapalnego (np. w okolicach stawu skokowego), jednak często precyzyjne ustalenie etiologii obrzęków nie było możliwe. Z tego powodu wielu reumatologów zajęło się badaniami nad etiologią obrzęku w RZS [1-3].

Terapie utrzymujące lub przywracające funkcje układu limfatycznego mogą odgrywać strategiczną rolę w ograniczaniu procesu zapalnego [4]. Wykazano, że blokowanie czynnika martwicy nowotworów (tumor necrosis factorTNF) stymuluje namnażanie się naczyń limfatycznych w obrębie zmienionej zapalnie błony maziowej u pacjentów z RZS. Zdaniem autorów stymulowanie limfangiogenezy może odgrywać ważną rolę w odpływie komórek i płynu ze zmienionych zapalnie tkanek [5].

W pracy zobrazowano włosowate naczynia limfatyczne pełniące ważną funkcję w procesie drenażu tkanki łącznej stanowiącej element strukturalny wielu narządów organizmu człowieka, w tym stawów maziówkowych.

Badania nad kapilarami limfatycznymi stawów maziówkowych człowieka prowadzono z zastosowaniem metod histochemicznych [5-7] oraz transmisyjnego mikroskopu elektronowego [8, 9].

W pracy przedstawiono wyniki badań morfologicznych włosowatych naczyń limfatycznych błony maziowej oraz wyraźne rozróżnienie pomiędzy ich budową a budową krwionośnych naczyń włosowatych i małych naczyń żylnych.

\section{Materiał i metody}

Tkankę maziową pobrano w trakcie zabiegu synowektomii stawu kolanowego u pacjentów z RZS i MIZS. Od wszystkich pacjentów, 4 kobiet i 1 mężczyzny, uzyskano pisemną świadomą zgodę. Charakterystykę pacjentów przedstawio-

Table I. Patients' age and disease duration

Tabela I. Wiek pacjentów i czas trwania choroby

\begin{tabular}{|llll|}
\hline $\begin{array}{l}\text { Patient / } \\
\text { Pacjent }\end{array}$ & $\begin{array}{l}\text { Age / } \\
\text { Wiek }\end{array}$ & $\begin{array}{l}\text { Disease duration before synovectomy (years) / } \\
\text { Czas trwania choroby przed synowektomiq } \\
\text { (w latach) }\end{array}$ & $\begin{array}{l}\text { Stage acc. to Steinbrocker scale / } \\
\text { Stopień zaawansowania choroby w skali } \\
\text { Steinbrockera }\end{array}$ \\
\hline A & 45 & 10 & $\mathrm{~N}$ \\
\hline B & 25 & 10 & $\mathrm{~N}$ \\
\hline C & 30 & 4 & $\mathrm{I}$ \\
\hline D & 35 & 11 & $\mathrm{~N}$ \\
\hline E & 31 & 11 &
\end{tabular}


Micrographs were taken under a light microscope (LEICA DMLS; Wetzlar, Germany). Ultrathin $(50 \mathrm{~nm})$ sections were cut on the same ultramicrotomes and stained with uranyl acetate and lead citrate. Electron micrographs were taken under a transmission electron microscope (TESLA BS500; Brno, Czech Republic).

\section{Results}

We demonstrate ultrastructure and structure (Fig. 1) of endothelial microvalves (specialized intercellular junctions). Endothelial microvalves are situated on the boundary between extravascular and intravascular parts of the microcirculation in the synovial joint. We assume that in rheumatoid arthritis the demands on function of endothelial microvalves are increased, because the LC have to drain large amounts of oedematous fluid, cells and detritus from the interstitium of synovial membrane into the lymphatic nodes. We repeatedly observed lymphocytes in close proximity to the walls of LC. We demonstrate them in Figs. 2 and 3.

Sometimes, only a few lymphocytes could be seen in the proximity of the thin wall of the LC. In several samples of synovial tissue we found greater accumulations of lymphocytes. Studies of serial sections allowed us to distinguish that the lymphocytes created perivascular infiltrates around the LC. In LC lumina we observed lymphocytes, macrophages (Figs. 1, 2) and cell debris (Fig. 3).

\section{Discussion}

Oedema is caused by accumulation of tissue fluid in tissues. The tissue fluid originates from blood by transudation through the blood capillary walls [2].

A high protein level is typical for oedematous fluid in RA. Oedematous fluid containing more than $10 \mathrm{~g} / \mathrm{l}$ of proteins is considered to be high-protein fluid, and signals the inflammatory origin of such oedema [3]. Casley-Smith and Gaffney [10] found evidence of protein changes in tissues as the cause of chronic inflammation.

Aiming at detection of possible abnormal lymphatic clearance in RA patients, Jayson et al. [11] administered iodine marked albumin intradermally and measured its elimination rate from subcutaneous tissue. The tissue fluid production in RA patients with oedemas was faster, which increased the rate of lymphatic drainage, although not enough to compensate rapid tissue fluid production.

The imbalance between the vessel permeability and tissue drainage results in the formation of oedema [12]. According to Ahlquist [13], synovial joints represent loci minores resistentiae for oedema formation in the presence of mild generalised exudation. The swelling of the joint develops if the fluid leakage rate from plasma exceeds the lymphatic drainage rate for a sufficiently long period of time. no w tabeli I. Próbki tkanek poddano procesowi utrwalenia, stosując 3\% roztwór glutaraldehydu przez 4 godziny, a następnie powtórnemu utrwaleniu $\mathrm{OsO}_{4}$, dehydratacji etanolem, działaniu tlenku propylenu, po czym zatopiono je w Durcupanie ACM (Fluka, Buchs, Szwajcaria). Półcienkie skrawki $(0,5 \mu \mathrm{m})$ przygotowano ultramikrotomem LKBHuxley (Bromma, Szwecja) lub Leica ULTRACUT R (Wiedeń, Austria) i poddano barwieniu błękitem toluidynowym. Zdjęcia mikrograficzne wykonano za pomocą mikroskopu świetlnego LEICA DMLS (Wetzlar, Niemcy). Ultracienkie skrawki (50 nm), uzyskane przy użyciu tych samych ultramikrotomów, zabarwiono octanem uranylu i cytrynianem ołowiu. Zdjęcia mikrograficzne wykonano pod transmisyjnym mikroskopem elektronowym TESLA BS500 (Brno, Republika Czech).

\section{Wyniki}

Przedstawiono strukturę i ultrastrukturę mikrozastawek śródbłonka (wyspecjalizowanych połączeń między komórkami) (ryc. 1). Mikrozastawki śródbłonka występują na granicy między przestrzenią pozanaczyniową i wewnątrznaczyniową mikrokrążenia stawów maziówkowych. Zakłada się, że w RZS występuje zwiększone obciążenie mikrozastawek śródbłonka, ponieważ włosowate naczynia limfatyczne muszą sprostać usuwaniu dużych ilości płynu obrzękowego, komórek i szczątków rozpadłej tkanki z przestrzeni śódmiąższowej błony maziowej do węzłów chłonnych. Wielokrotnie obserwowano limfocyty w bliskim sąsiedztwie ścian kapilar limfatycznych (ryc. 2 i 3 ).

Niekiedy liczba limfocytów widocznych w sąsiedztwie cienkiej ściany włosowatych naczyń limfatycznych była niewielka. W kilku próbkach tkanki maziowej stwierdzono większe skupiska limfocytów. Badania seryjnych skrawków umożliwiły zaobserwowanie limfocytów tworzących nacieki okołonaczyniowe wokół kapilar limfatycznych. W świetle włosowatych naczyń limfatycznych zaobserwowano limfocyty, makrofagi (ryc. 1, 2) oraz szczątki komórkowe (ryc. 3).

\section{Omówienie}

Obrzęk jest wynikiem nagromadzenia się płynu tkankowego w tkankach. Płyn tkankowy pochodzi z krwi i powstaje w wyniku przesiąkania przez ścianę kapilarów krwionośnych [2].

Duże stężenie białek jest typowe dla płynu obrzękowego w RZS. Uważa się, że płyn obrzękowy, w którym zawartość białka przekracza 10 g/l, jest płynem wysokobiałkowym i wskazuje na zapalne pochodzenie takiego obrzęku [3]. Casley-Smith i Gaffney [10] przedstawili dowody na to, że zmiany w składzie białek w tkankach wywołują przewlekły stan zapalny.

W celu wychwycenia ewentualnych nieprawidłowości w odpływie chłonki u pacjentów z RZS, Jayson i wsp. [11] podali pacjentom śródskórnie znakowaną jodem albuminę 

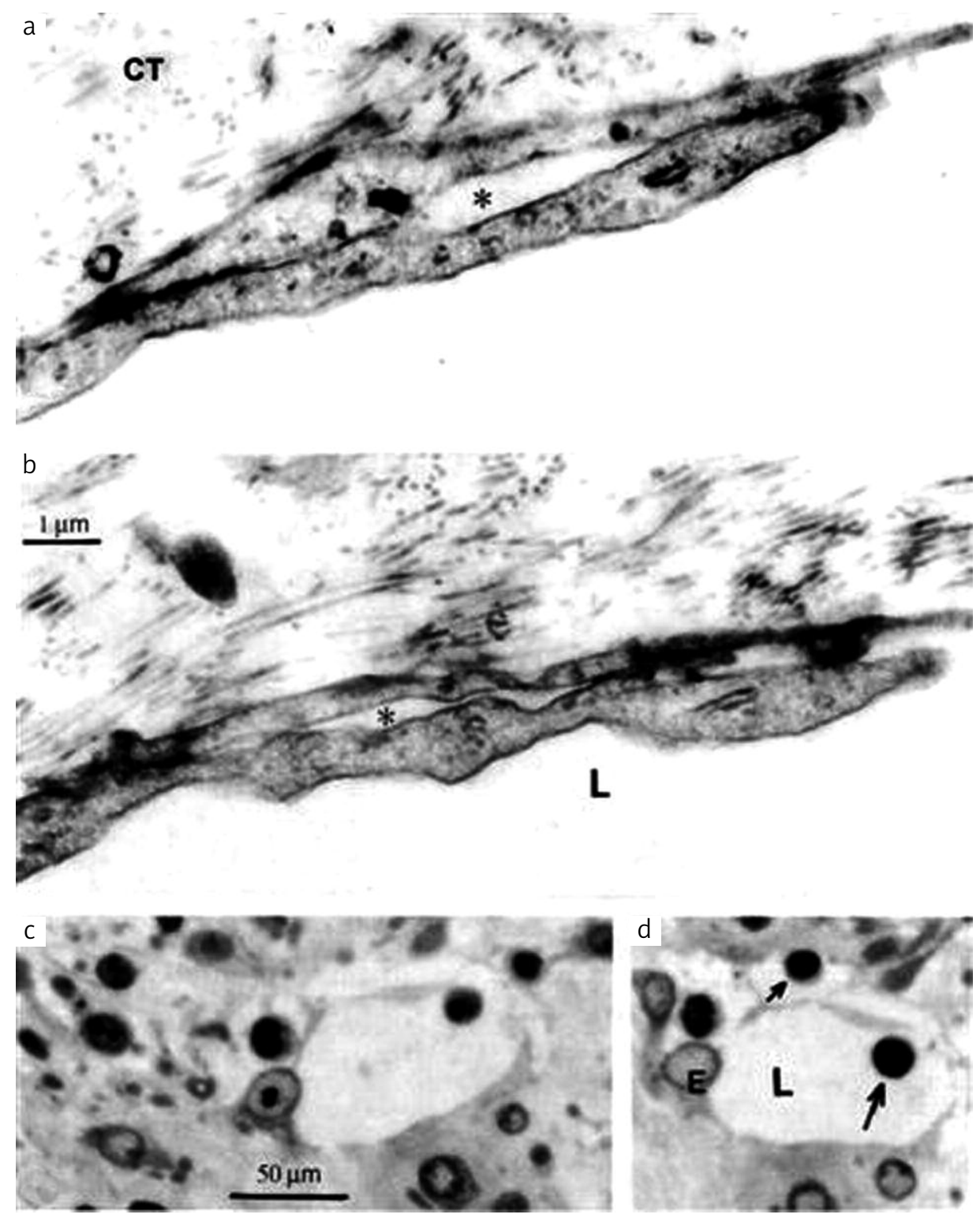

Fig. 1. Electronograms and microphotographs of endothelial microvalves in lymphatic capillaries of the synovial membrane from a JIA female patient.

a, b) Ultrastructure of specialized intercellular junctions - endothelial microvalves. They are formed by overlapping flaps of the adjacent endothelial cells. The fibres from the surrounding connective tissue (CT) are attached to the outer flap. Small interspaces (asterisks) are visualized between the inner and outer flap. Ultrathin sections stained with uranyl acetate and lead citrate.

c, d) A lymphocyte (arrow) which entered the lymphatic capillary lumen (L) through an open endothelial microvalve. Another lymphocyte (small arrow) is situated in the pre-lymphatic tissue channel - on its way into the capillary lumen from the interstitium. Semithin sections stained with toluidine blue.

Ryc. 1. Zdjęcia wykonane mikroskopem elektronowym i mikrofotografie mikrozastawek śródbłonka włosowatych naczyń limfatycznych błony maziowej pacjentki z MIZS.

a, b) Ultrastruktura wyspecjalizowanych połączeń między komórkami - mikrozastawek śródbłonka. Mikrozastawki tworza się w wyniku nachodzenia na siebie płatków sasiadujacych ze soba komórek śródbłonka. Włókna pochodzace z otaczajacej tkanki tącznej (connective tissue - CT) sa przytwierdzone do zewnętrznego płatka. Pomiędzy wewnętrznym i zewnętrznym płatkiem widoczne sa mate odstępy (gwiazdki). Ultracienkie skrawki barwione octanem uranylu i cytrynianem ołowiu.

c, d) Limfocyt (strzałka), który wnikną do światła (lumen - L) włosowatego naczynia limfatycznego przez otwarta mikrozastawkę śródbłonka. Kolejny limfocyt (mała strzatka) jest widoczny w kanale przedlimfatycznym - w drodze do światta naczynia włosowatego z przestrzeni śródmiąższowej. Skrawki półcienkie barwione błękitem toluidyny. 


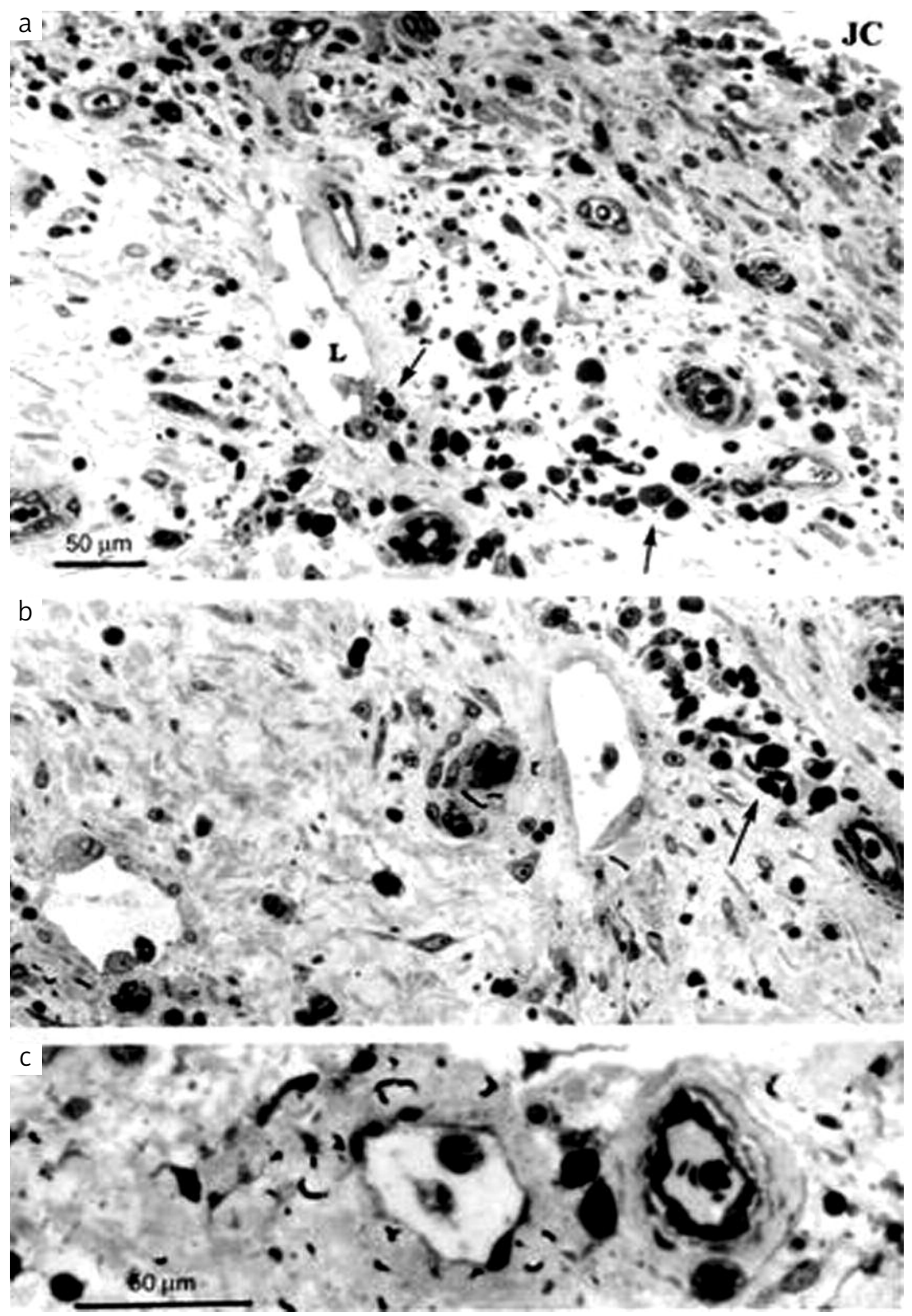

Fig. 2. A microphotograph of semi-thin sections from the synovial membrane.

a) A lymphatic capillary (L) contains a lymphocyte, a macrophage and cell debris in the lumen. Infiltrating cells accumulated in the interstitium (large arrow) extend in the direction of the lymphatic capillary. On the way to the capillary lumen, several cells (small arrow) are accumulated next to the enlarged endothelial cell. JC - joint cavity.

b) Mononuclear cells (arrow) accumulated in the interstitium between the lymphatic capillary and venules.

c) Macrophages and debris in the lymphatic capillary lumen, situated next to the venule. Semithin sections stained with toluidine blue.

Ryc. 2. Mikrofotografia pótcienkich skrawków błony maziowej.

a) W świetle włosowatego naczynia limfatycznego (lymphatic capillaries - LC) znajduja się limfocyt, makrofag oraz szczątki komórkowe. Naciekające komórki zgromadzone w przestrzeni śródmiąższowej (duża strzałka) ciągną się w kierunku włosowatego naczynia limfatycznego. W drodze do światła naczynia włosowatego, kilka komórek (mała strzałka) skupiło się w pobliżu powiększonej komórki śródbłonka. JC - jama stawu (joint cavity).

b) Komórki jednojądrowe (strzałka) skupione w przestrzeni śródmiąższowej pomiędzy włosowatymi naczyniami limfatycznymi a matymi naczyniami żylnymi.

c) Makrofagi i szczątki w świetle włosowatego naczynia limfatycznego, położonego w sąsiedztwie małego naczynia żylnego. Skrawki pótcienkie barwione błękitem toluidyny. 


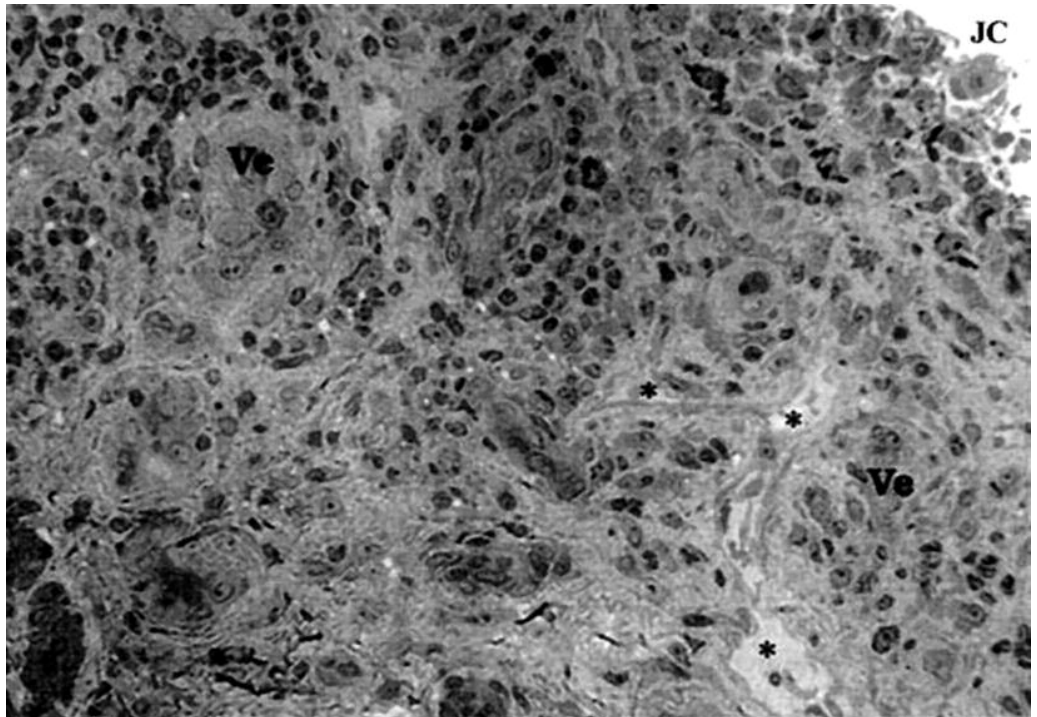

Fig. 3. Synovial membrane with hyperplastic lining cell layer.

Visible perivascular infiltrates comprising mononuclear cells are seen around the venules (Ve). Irregular shape of the lumen of the lymphatic capillary (asterisks) situated next to the venules is formed by accumulation of infiltrating cells in the interstitium. The capillary lumen is filled with debris. JC - joint cavity. Semithin section stained with toluidine blue.

Ryc. 3. Błona maziowa z przerośniętą warstwą komórek wyściełających.

Widoczne nacieki okołonaczyniowe składajace się z komórek jednojądrowych wokót małych naczyń żylnych (venules - Ve). Nieregularny ksztatt światta włosowatego naczynia limfatycznego (gwiazdki) położonego w sąsiedztwie matych naczyń żylnych powstat w wyniku nagromadzenia się komórek naciekajacych przestrzeń śródmiaższowa. Światło naczynia włosowatego wypetniaja szczatki. JC-jama stawu (joint cavity). Skrawki pótcienkie barwione btękitem toluidyny.

According to his opinion, synovial joint swelling indicates relative lymphatic insufficiency.

Tissue fluid found in the cavity of synovial joints is called synovial fluid. The analyses of human synovial fluid have shown a low and variable nucleated cell count (13-180 cells/ $\mu \mathrm{l})$. Mononuclear phagocytes have the largest representation. Their main task is to remove the wearand-tear debris, caused by everyday micro traumas [14]. The amount of synovial fluid in some joints can increase in RA, and is called synovial effusion.

Synovial effusions from joints affected by rheumatoid synovitis belong to high-protein oedemas. Based on the opinion of lymphologists, the presence of high-protein oedema signals insufficient removal of proteins by two mechanisms: tissue proteolysis and removal via lymphatic vessels [15].

Proteolysis in tissues is performed by multiple types of cells of which macrophages are the most important. While the role of macrophages remains important for inflammation, we should not forget that they are present and active in healthy tissue as well. It has been found that $1 \mathrm{~cm}^{3}$ of loose connective tissue contains approximately $10^{7}$ macrophages. Their amount increases during the inflammatory process (almost tenfold)

Synovial membrane in RA is hypertrophic and oedematous. Histology findings include hyperplasia of synovial lining cells and accumulation of multiple cell populations i oznaczyli wskaźnik jej eliminacji z tkanki podskórnej. Tempo wytwarzania płynu tkankowego u pacjentów z RZS z obrzękami było większe, co skutkowało wzrostem tempa drenażu limfatycznego, jednak nie do takiego stopnia, aby zrównoważyć wysokie tempo powstawania płynu tkankowego.

Brak równowagi między przepuszczalnością naczyń a drenażem tkanek prowadzi do powstawania obrzęków [12]. Według Ahlquista [13] stawy maziówkowe stanowią loci minores resistentiae (punkty najmniejszego oporu) dla tworzenia się obrzęków w obecności niewielkiego stopnia wysięku uogólnionego. Do obrzęku stawu dochodzi w sytuacjach, w których tempo przenikania płynu z osocza przekracza przez dostatecznie długi czas tempo drenażu limfatycznego. Zdaniem tego autora obrzęk stawu maziówkowego wskazuje na względną niewydolność limfatyczną.

Płyn tkankowy znajdujący się w jamach stawów jest nazywany płynem maziowym. Badania płynu maziowego człowieka wykazały małe i zmienne ilości komórek jądrowych (13-180 komórek/ $\mu$ l). Fagocyty jednojądrowe stanowią najliczniejszą grupę. Głównym zadaniem tych komórek jest usuwanie „zużytych” szczątków powstałych w wyniku codziennych mikrourazów [14]. Objętość płynu maziowego w niektórych stawach może wzrastać w RZS i jest określane mianem wysięku błony maziowej.

Wysięki błony maziowej ze stawów objętych reumatoidalnym zapaleniem błony maziowej zaliczają się do 
(T-cells, plasmatic cells, B-cells, macrophages, neutrophils, mast cells, natural killers and dendritic cells) in connective tissue under lining cells. Lymphocytes make up a significant part of infiltrates in rheumatoid arthritis. Diapedesis of lymphocytes from blood circulation into synovial membrane in RA takes place via small blood vessels that resemble venules in the lymph node paracortex [16]. On entry of lymphocytes and other cells into synovial tissue in RA and during cell interactions an important role is played by adhesive molecules and cytokine receptors located on cell membranes of leukocytes and endothelial cells of both blood and lymphatic vessels [17-19].

The interstitium is an integral part of microcirculation in connective tissue. Hauck [20] presented evidence of a fully opened system of tissue channels in the interstitium. According to his opinion, the tissue channels form a network within connective tissue, converging on lymphatic capillaries. Tissue channels represent the primary (elementary) drainage system of connective tissue. The system of tissue channels functions also in the nutrition of avascular joint cartilage and pre-lymphatic drainage of the joint cavity.

The evidence presented by the studies on physiology show that the synovial membrane interstitium plays an important role in protein drainage from the joint cavity into LC $[21,22]$.

$\mathrm{LC}$ also enable the physiological recirculation of lymphocytes. Most of the mature lymphocytes continuously circulate from the blood into tissues and back again into the bloodstream through lymph at a rate of one or two times a day. The lymphocytes act as an immunological supervisor during the recirculation in tissues. The migration of subpopulations of small lymphocytes is tissuespecific [23].

The products of the inflammatory process from joints in RA are drained via lymphatic vessels into the lymph nodes. In 2001, Olszewski et al. [24] reported to have found that the average lymph flow rate from cannulated prenodal lymphatic vessels in RA patients doubled as compared with healthy individuals in the control group. They reported the standard cell concentration in the lymph to be $5-120 / \mu$ l and double in RA patients. Recently, apoptosis has been observed in $20 \%$ of lymphocytes in prenodal lymph cannulated from superficial lymphatic vessels of lower limbs in healthy individuals [25].

As early as in 1937, Pullinger and Florey [26] found evidence that debris was removed from the tissues affected by inflammation by the lymphatic vessels either directly or through phagocytic cells. We found macrophages and cell debris in the lumen of synovial LC from patients with RA and JIA. Pullinger and Florey [27] reported proliferation of lymphatic capillaries in skin inflammation. Proliferation of synovial lymphatic vessels was reported in RA patients after obrzęków wysokobiałkowych. Zdaniem specjalistów chorób układu limfatycznego obecność obrzęku wysokobiałkowego sygnalizuje niedostateczne usuwanie białek za pośrednictwem obu mechanizmów: proteolizy tkanek oraz przez naczynia limfatyczne [15].

W procesie proteolizy tkanek uczestniczy wiele rodzajów komórek, z których najważniejszą grupę stanowią makrofagi. Pamiętając o ważnej roli makrofagów w procesach zapalnych, należy także brać pod uwagę ich obecności i aktywności w obrębie zdrowych tkanek. Stwierdzono, że w $1 \mathrm{~cm}^{3}$ luźnej tkanki łącznej znajduje się ok. $10^{7}$ makrofagów. Ich liczba zwiększa się w przebiegu procesu zapalnego (prawie 10-krotnie).

Błona maziowa w RZS jest zmieniona hipertroficznie i obrzęknięta. W badaniach histologicznych stwierdzono m.in. przerost komórek wyściółki błony maziowej i skupiska składające się z licznych populacji komórkowych (limfocyty T, komórki plazmatyczne, limfocyty B, makrofagi, neutrofile, komórki tuczne, naturalne komórki cytotoksyczne oraz komórki dendrytyczne) pod warstwą komórek wyściółki tkanki łącznej. Limfocyty stanowią istotną część składową nacieków w RZS. Diapedeza limfocytów z krwiobiegu do błony maziowej w RZS odbywa się za pośrednictwem drobnych naczyń krwionośnych przypominających małe naczynia żylne w strefie przykorowej węztów chtonnych [16]. W procesie przenikania limfocytów oraz innych komórek do tkanki maziowej w RZS i podczas interakcji międzykomórkowych ważną rolę odgrywają cząsteczki adhezyjne i receptory cytokin obecne na błonie komórkowej leukocytów i komórek śródbłonka, zarówno naczyń krwionośnych, jak i limfatycznych [17-19].

Przestrzeń śródmiąższowa stanowi integralną część mikrokrążenia w tkance łącznej. Dowody na obecność wewnątrztkankowego otwartego systemu kanałów w przestrzeni śródmiąższowej przedstawił Hauck [20], którego zdaniem kanały tworzą sieć wewnątrz tkanki łącznej, schodząc się do włosowatych naczyń limfatycznych. Wewnątrztkankowe kanały są głównym układem drenującym tkankę łączną. System wewnątrztkankowych kanałów pełni również funkcje odżywcze dla chrząstki stawowej pozbawionej unaczynienia oraz uczestniczy w przedlimfatycznym drenażu jamy stawu.

Dowody pochodzące z badań nad fizjologią wykazują, że błona maziowa przestrzeni śródmiąższowej odgrywa ważną rolę w drenażu białek z jamy stawu do kapilarów limfatycznych [21, 22].

Włosowate naczynia limfatyczne umożliwiają również fizjologiczną recyrkulację limfocytów. Większość dojrzałych limfocytów krąży w sposób ciągły pomiędzy krwią a tkankami i z powrotem do krwiobiegu za pośrednictwem chłonki, wykonując 1-2 okrążenia na dobę. Limfocyty pełnią funkcję immunologicznego nadzorcy procesu recyrkulacji w tkankach. Migracja subpopulacji małych limfocytów charakteryzuje się swoistością tkankową [23]. 
treatment with anti-TNF antibody [5]. Conspicuous LC were described in synovial membrane in 2005 [28]. Wilkinson and Edwards [7] provided visualisation of lymphatic vessels situated in the proximity of deep arterioles and venules of the human synovial membrane using lectin Ulex europaeus agglutinin I (UEAI); however, using this method in RA patients, the samples did not show any lymphatic vessels. The authors concluded that the result suggests either the absence of lymphatic vessels in rheumatoid synovial membrane or a change in the phenotype of their endothelium.

The described findings raise further questions: Do the cells of the immune system, accumulated in the interstitium of synovial membrane in rheumatoid synovitis, have preserved functional ability to migrate through the connective tissue into the lymphatic capillaries? Are the endothelial cells of the lymphatic capillary walls changed in synovitis to such an extent that they do not allow entry of cells from the interstitium into the capillary lumen? To answer these questions requires further studies. It may be said that the accumulation of cellular infiltrates (perivascular, diffuse and nodular) in synovial tissue may cause disorder in the microcirculation.

The authors declare no conflict of interest.
Produkty procesu zapalnego przebiegającego w stawach pacjentów z RZS są usuwane za pośrednictwem naczyń limfatycznych do węzłów chłonnych. W 2001 r. Olszewski i wsp. [24] stwierdzili 2-krotnie szybsze średnie tempo przepływu chłonki w kaniulowanych przedwęzłowych naczyniach limfatycznych pacjentów z RZS w porównaniu ze zdrowymi osobami z grupy kontrolnej. W swoich doniesieniach autorzy ci podali, że standardowa liczba komórek w chłon-

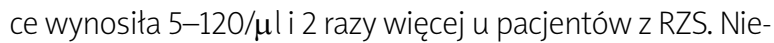
dawno zaobserwowano zjawisko apoptozy w 20\% limfocytów w chłonce przedwęzłowej z kaniulowanych powierzchownych naczyń limfatycznych kończyn dolnych osób zdrowych [25].

Już w 1937 r. Pullinger i Florey [26] przedstawili dowody na usuwanie resztek z tkanek objętych procesem zapalnym drogą naczyń limfatycznych, bezpośrednio lub za pośrednictwem komórek fagocytarnych. Stwierdziliśmy obecność makrofagów i resztek komórek w świetle włosowatych naczyń limfatycznych błony maziowej pacjentów z RZS i MIZS. Pullinger i Florey [27] opisali namnażanie się kapilarów limfatycznych w przebiegu zapalenia skóry. Istnieją doniesienia o namnażaniu się naczyń limfatycznych błony maziowej u pacjentów z RZS po leczeniu przeciwciałami anty-TNF [5]. W 2005 r. opisano wyraźnie widoczne włosowate naczynia limfatyczne w błonie maziowej [28]. Wilkinson i Edwards [7] dostarczyli zdjęcia naczyń limfatycznych zlokalizowanych w pobliżu głęboko położonych tętniczek i małych naczyń żylnych ludzkiej błony maziowej przy użyciu lektyny z kolcolistu zachodniego (lectin Ulex europaeus agglutinin I - UEAAI); jednak przy zastosowaniu tej metody u pacjentów z RZS badane próbki nie wykazały obecności naczyń limfatycznych. Autorzy doszli do wniosku, że wyniki sugerują brak naczyń limfatycznych w obrębie reumatoidalnie zmienionej błony maziowej lub też zmianę w fenotypie śródbłonka.

Przedstawione wyniki nasuwają kolejne pytania: Czy komórki układu odpornościowego nagromadzone w przestrzeni śródmiąższowej błony maziowej w reumatoidalnym zapaleniu błony maziowej mają zachowaną zdolność migracji przez tkankę łączną do włosowatych naczyń limfatycznych? Czy komórki śródbłonka ścian kapilarów limfatycznych są do takiego stopnia zmienione w wyniku zapalenia błony maziowej, że nie pozwalają na przejście komórek z przestrzeni śródmiąższowej do światła naczyń włosowatych? Uzyskanie odpowiedzi na te pytania wymaga przeprowadzenia dalszych badań. Można stwierdzić, że obecność nacieków komórkowych (okołonaczyniowych, rozsianych i guzkowych) w tkance maziowej może wywołać zaburzenia w mikrokrążeniu.

Autorzy deklarują brak konfliktu interesów. 


\section{References}

\section{Piśmiennictwo}

1. Kalliomäki JL, Vastamäki M. Chronic diffuse oedema of the rheumatoid hand a sign of local lymphatic involvement. Ann Rheum Dis 1968; 27: 167-169.

2. Jayson MIV, Barks JS. Oedema in rheumatoid arthritis: changes in the coefficient of capillary filtration. Brit Med J 1971; 2: 555-557.

3. Gandy RH, Anseli BM, Bywaters EGL. Protein concentration of oedema fluid in oedema fluid in rheumatoid arthritis. Ann Rheum Dis 1965; 24: 234-238.

4. Chaitanya GV, Franks SE, Cromer V, et al. Differential cytokine responses in human and mouse lymphatic endothelial cells to cytokines in vitro. Lymph Res Biol 2010; 8: 155-164.

5. Polzer K, Baeten D, Soleiman A, et al. Tumor necrosis factor blockade increases lymphangiogenesis in murine and human arthritic joints. Ann Rheum Dis 2008; 67: 1610-1616.

6. Xu H, Edwards J, Banerji S, et al. Distribution of lymphatic vessels in normal and arthritis human synovial tissues. Ann Rheum Dis 2003; 62: 1227-1229.

7. Wilkinson LS, Edwards JCW. Demonstration of lymphatics in human synovial tissue. Rheumatol Int 1991; 11: 151-155.

8. Rovenská E, Rovenský J. Lymphatic vessels: structure and function. IMAJ 2011; 13: 762-768.

9. Rovenská E, Rovenská E Jr, Neumüller J. Structure of synovial lymphatic capillaries in rheumatoid arthritis and juvenile idiophatic arthritis. Int J Tissue React 2003; 24: 29-38.

10. Casley-Smith JR, Gaffney RM. Excess plasma proteins as a cause of chronic inflammation and lymphoedema: quantitative electron microscopy. J Pathology 1981; 133: 243-272.

11. Jayson MIV, Cavill I, Barks JS. Lymphatic clearance rates in rheumatoid arthritis. Ann Rheum Dis 1971; 30: 638-639.

12. Witte MH, Witte ChL. Lymph formation > lymph absorption: The formula of oedema. Lymphology 1973; 6: 101-109.

13. Ahlquist J. Swelling of synovial joints - An anatomical, physiological and energy metabolical approach. Pathophysiology 2000; 7: 1-19.

14. Gardner DL. Pathological basis of connective tissue discases. Edward Arnold, London-Melbourne-Auckland 1992.

15. Földi M, Casley-Smith JR. The roles of the lymphatics and the cells in high-protein oedemas. Molec. Aspects Med 1978; 2: 77-146.

16. Freemont $\mathrm{A}$, Jones CJP, Bromley $\mathrm{M}$, et al. Changes in vascular endothelium related to lymphocyte collections in disead [RA1]synovia. Arthritis Rheum 1983; 26: 1427-1433.

17. Jalkanen S, Steere AC, Fox RI, et al. A distinct endothelial cell recognition system that controls lymphocyte traffic into inflammed synovium. Science 1986; 233: 556-558.

18. Maini RN. Exploring immune pathways in rheumatoid arthritis. Br J Rheumatol 1988; 28: 6: 466-479.

19. Pitzalis C. Adhesion, migration, and cell trafficking. In: Rheumatoid arthritis. New frontiers in pathogenesis and treatment. Firenstein GS, Panayi GS, Wollheim FA (eds.). Oxford University Press, Oxford 2000; 137-146.

20. Hauck $G$. The connective tissue in view of the lymphology. Experientia (Basel) 1982; 38: 1121-1222.

21. Levick JR, McDonald JN. Fluid movement across synovium in healthy joints: role of synovial fluid macromolecules. Ann Rheum Dis 1995; 54: 417-423.

22. Simkin PA. Synovial perfusion and synovial fluid solutes. Ann Rheum Dis 1995; 54: 424-428.
23. Abernethy NJ, Hay JB. The recirculation of lymphocytes from blood to lymph: physiological considerations and molecular mechanisms. Lymphology 1992; 25: 1-30.

24. Olszewski WL, Pazdur J, Kubasiewicz E, et al. Lymph draining from foot joints in rheumatoid arthritis provides insight into local cytokine and chemokine production and transport to lymph nodes. Arthritis Rheum 2001; 44: 541-549.

25. Olszewski WL. Human afferent lymph contains apoptotic cells and "free" apoptotic DNA fragments - can DNA be reutilised by the lymph node cells? Lymphology 2001; 34: 179-183.

26. Pullinger BD, Florey HW. Some observations on the structure and functions of lymphatics: their behaviour in local oedema. Brit J Exp Pathol 1935; 16: 49-61.

27. Pullinger BD, Florey HW. Proliferation of lymphatics in inflammation. J Pathol 1937; 45: 157-170.

28. Rovenská E, Štvrtina Š, Greguška O, et al. Conspicuous synovial lymphatic capillaries in juvenile idiopathic arthritis synovitis with rice bodies. Ann Rheum Dis 2005; 64: 328-329. 